\section{Exposés, the EU and implementing Article 5.3}

\author{
Mike Daube
}

The modern era of ever more complex governmental processes, multi-government groupings such as the European Union, and overarching international legislation and agreements stacks the dice in favour of large global corporations. Tobacco companies have the resources needed to keep track of all the different processes, to use them to best advantage, to find legal and procedural highways and byways that will further confuse and delay, to generate support from groups directly and indirectly associated with them, and to lobby, lobby, lobby.

Building on the cornucopia of documents made available following the US Master Settlement Agreement, there is a substantial and growing literature on the way the companies work; websites such as Tobacco Tactics ${ }^{1}$ ensure that much of this is readily accessible; at least some of the extraordinary level of funding devoted by tobacco and other industries to lobbying in the EU has been well documented; and judicial concern has been raised at the highest levels around the way global companies can use inter-governmental processes to override the powers of individual governments. ${ }^{2}$ Further, while industry approaches may have become a touch more subtle since 1973, when this author was offered generous funding by the chairman of a major tobacco company to work on any campaign other than tobacco, there is also an ample literature on the use of financial incentives at all levels to subvert health agendas-not least in the EU.

So why is the paper by Costa $e t a l^{3}$ so different and important?

The EU Tobacco Products Directive (TPD) was clearly seen by the industry as a major target. One advantage of the EU's amazingly complex processes is that they provide a window into the way tobacco companies and their allies work to influence public policy. This meticulous analysis shows how tobacco control researchers can make innovative use of approaches developed in other disciplines

Correspondence to Dr Mike Daube, Public Health Advocacy Institute, Curtin University, GPO Box U1987, Perth, WA 6845, Australia; m.daube@curtin.edu.au (in this case political science) to broaden the evidence base. It provides valuable further evidence on the way tobacco companies work with and through allied groups as part of the lobbying process. And crucially, it shows that the industry's lobbying worked. The European Union's core values are "human dignity, freedom, democracy, equality, the rule of law and respect for human rights" ${ }^{4}$; yet this paper demonstrates beyond any reasonable doubt that its positions moved to wording preferred by tobacco companies, and the resultant tobacco control legislation was heavily influenced and watered down by the industry.

Costa and colleagues have, quite simply, shown that the EU's processes can be subverted by an evil industry with the capacity to out-spend, out-lobby and outlast health authorities.

So where next? Tobacco companies will always have more funding than health groups for direct and indirect lobbying. It is vital that health researchers maintain and step up their work in exposing the industry's approaches and successes, and are supported by funders who understand the importance of industry monitoring. Every exposé such as this (and others that have come from EU processes) embarrasses those who have succumbed to pressure, and makes the industry's task harder next time around.

It may also be time to reconsider the way Article 5.3 of the FCTC $^{5}$ is viewed and implemented. We cannot properly protect public health policies on tobacco control from the vested interests of the industry while our governmental or supragovernmental processes allow them both direct and ready access to decisionmakers, and the capacity to intervene in decision-making processes. In the case of the TPD, they clearly had good access to decision-makers; they and their allies sought to sabotage the original intent of the TPD through many lengthy and misleading submissions; and they were able to delay the process until it reached a resolution with which they could live.

When the Australian Government established the National Preventative Health Taskforce in 2008, the Health Minister,
Nicola Roxon was explicit about consultation with industry. The Taskforce was instructed to consult with alcohol, food, pharmaceutical and other industries-but not tobacco. While the industry was able to make submissions (as was anyone else in the community), we did not have to meet with the companies, or respond to their submissions and lobbying efforts. That is surely the way in which Article 5.3 should be observed by all governments: we know from decades of experience that given even a glimpse of an open door, the industry's lobbyists will pile through it at speed and in vast numbers.

It is clear that the EU has not treated tobacco as the pariah industry envisaged by Article 5.3. To ensure that this happens, public health researchers should continue to monitor, analyse and expose the fundamentally anti-health approach taken both by tobacco companies and, in their willingness to support industry objectives, by too many governments.

Competing interests None.

Provenance and peer review Commissioned; internally peer reviewed.

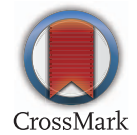

To cite Daube M. Tob Control 2014;23:461.

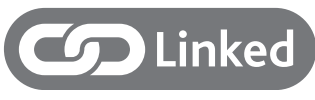

- http://dx.doi.org/10.1136/tobaccocontrol-2014051822

Tob Control 2014;23:461

doi:10.1136/tobaccocontrol-2014-051885

\section{REFERENCES}

1 Tobacco Control Research Group. Tobacco Tactics [Internet]. Bath, UK: Department for Health, University of Bath, 2014 [updated 7 September 2014; cited 29 September 2014]. http://www.tobaccotactics.org/

2 French R. Investor-state dispute settlement-a cut above the courts? Speech by Chief Justice RS French $A C$ at Supreme and Federal Courts Judges' Conference. Darwin, Australia, 9 July 2014. http:// www.hcourt.gov.au/assets/publications/speeches/ current-justices/frenchcj/frenchcj09jul14.pdf

3 Costa H, Gilmore A, Peeters S, et al. Quantifying the influence of tobacco industry on EU governance: automated content analysis of the EU Tobacco Products Directive. Tob Control 2014;23:473-8.

4 European Union. How the EU works [Internet]. Brussels, Belgium: European Union, 2014 [cited 29 September 2014]. http://europa.eu/about-eu/index_en.htm

5 World Health Organization. WHO framework convention on tobacco control. Geneva, Switzerland, 2005. http://whqlibdoc.who.int/publications/2003/ 9241591013.pdf 